\title{
Peculiarities of calculation and design of slabs on elastic cushion reinforced with non-metallic composite reinforcement
}

\author{
Olena Luhchenko ${ }^{1 *}$, Ali Nazhem ${ }^{1}$, and Dmitriy Oreshkin ${ }^{2}$ \\ ${ }^{1}$ O.M. Beketov National University of Urban Economy in Kharkiv, 17 Marshala Bazhanova str., \\ Kharkiv, Ukraine \\ ${ }^{2}$ Ekipazh Technological group, Kharkiv, Ukraine
}

\begin{abstract}
Fiber-glass composite reinforcement becomes increasingly popular in different spheres of industry and public economy. Unique technology of the reinforcement production allows receiving the high-quality construction material which complies with modern requirements of liability, quality and safety. Pavlivska Square in Kharkiv may serve as an example of efficient application of non-metallic composite reinforcement for the reinforcement of slabs on elastic cushion during the construction of which the composite grids SKS-100/100 manufactured by Ekipage Technological Group were used as the reinforcement units. Pavement slab reinforcement scheme (including the working draft) was elaborated by the specialists of the Building Constructions Department of O.M. Beketov National University of Urban Economy. The arrangement of the pavement slab of Pavlivska Square was conducted within the short period of time. Due to this, for the purpose of mounting the two-layer reinforcing cage of the slab, the workers of Ekipage Technological Group elaborated a new mounting method which allows the essential reduction of the performance time.
\end{abstract}

\section{Introduction}

Today the fiber-glass and basalt-plastic composite reinforcement becomes increasingly popular in different spheres of industry and public economy. Unique technology of the reinforcement production allows receiving the high-quality construction material which complies with modern liability, quality and safety requirements. Noteworthy, the composite reinforcement is undemanding as to the application environment $[5,7,8,12]$. Thus, reinforcement may be used at different temperatures, from $-700^{\circ} \mathrm{C}$ up to $+1000^{\circ} \mathrm{C}$. However, the demand for this material is conditioned, first of all, by the fact that the fiberglass reinforcement is resistant against corrosion and has longer service life [8-10, 12]. The practicability if replacement the metal reinforcement by composite is constituted by a number of advantages, mainly: tear resistance is two times higher than the strength properties of the steel reinforcement A400C; stainless material; the reinforcement is acidresistant, works well in the sea water; the reinforcement does not bend (higher elasticity); is

\footnotetext{
*Corresponding author: elenalugchenko@gmail.com
} 
non-conductive, is dielectric; is not heat-transmitting; is radio-transparent; is magnetically inert (the change of the strength properties of the composite reinforcement under the impact of electro-magnetic fields is excluded); does not lose its strength properties under the influence of very low temperatures; is 5 times lighter than the metal reinforcement, and at the replacement equal in strength is 9 times lighter; any construction length; economic efficiency (reduction of transportation costs) [11]. The comparative characteristics of the metal and fiber-glass reinforcement are shown in Table 1. Based on the data received after many years of studies, a set of regulatory documents was elaborated regulating the application of non-metallic composite reinforcement and items there of for the construction purposes in different countries [2,3].

Table 1. Replacement equal in strength according to physical and chemical properties.

\begin{tabular}{|c|c|}
\hline Metal class A400C & $\begin{array}{c}\text { Composite polymeric fiber-glass } \\
\text { reinforcement AKS }\end{array}$ \\
\hline $6 \mathrm{~A} 400 \mathrm{C}$ & $4 \mathrm{AKS}$ \\
\hline $8 \mathrm{~A} 400 \mathrm{C}$ & $5.5 \mathrm{AKS}$ \\
\hline $10 \mathrm{~A} 400 \mathrm{C}$ & $6 \mathrm{AKS}$ \\
\hline $12 \mathrm{~A} 400 \mathrm{C}$ & $8 \mathrm{AKS}$ \\
\hline $14 \mathrm{~A} 400 \mathrm{C}$ & $10 \mathrm{AKS}$ \\
\hline $16 \mathrm{~A} 400 \mathrm{C}$ & $12 \mathrm{AKS}$ \\
\hline $18 \mathrm{~A} 400 \mathrm{C}$ & $14 \mathrm{AKS}$ \\
\hline $20 \mathrm{~A} 400 \mathrm{C}$ & $16 \mathrm{AKS}$ \\
\hline
\end{tabular}

\section{Project solution}

Pavlivska Square in Kharkiv may serve as the example of efficient application of nonmetallic composite reinforcement of slabs on elastic cushion (Fig. 1) during the construction of which the composite grids SKS-100/100 manufactured by Ekipage Technological Group were used as the reinforcement units [5-7].

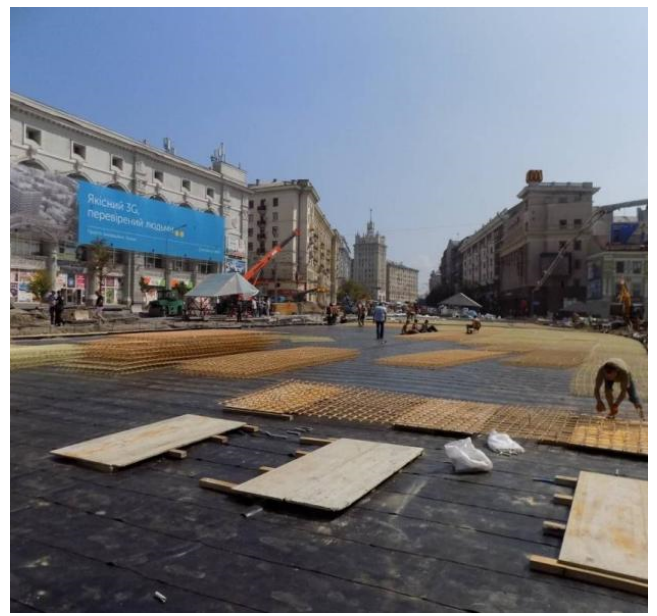

(a)

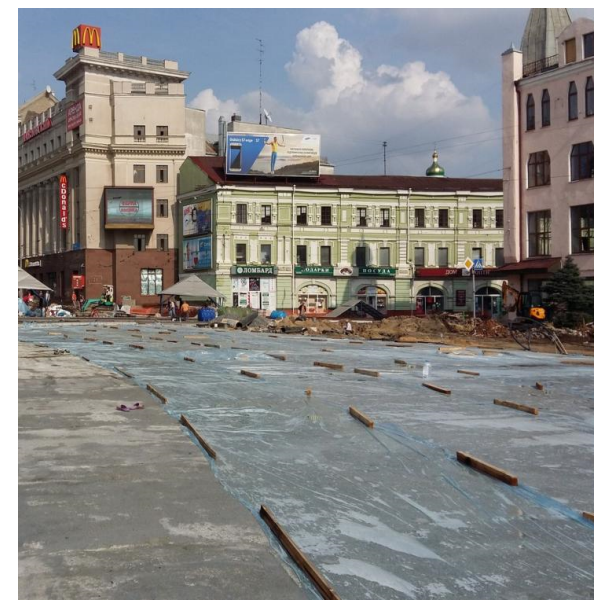

(b)

Fig. 1 a, b. Standard form of the pavement slab in Pavlivska sq., Kharkiv.

The square is located in the central part of Kharkiv. The location is unfavorable, primarily, due to a high location and essential fluctuations of the ground water level (GWL). During the floods GWL may reach the land surface. Besides, the soils occurring on such territories, as a 
rule, have a poor load bearing capacity; they are non-uniform, poorly consolidated, and saturated with water. The sands are quick. The quaternary deposits represented by modern filling layer take part in the geological construction. The filling layer is represented by the humous clay loam and sand with the construction waste, broken brick and break stone. It is $0.6-2.1 \mathrm{~m}$ strong; occurring everywhere. The ground waters of the underground reservoir have the following properties with regard to the material: concretes - slightly aggressive for all makes of concrete; reinforced concrete - medium-aggressive during the periodic immersion; metal constructions - highly aggressive. The factors above constitute the reason for the composite reinforcement application at this object.

\section{Static calculations of slabs}

The slab calculation shall be performed in compliance with $[1,11]$. Slab loading according is 25 tons on axis (loading NK-100). In case of infinitely great slab bearing the localized loading P. Load deflection reaches the maximum value

$$
\omega_{\max }=\frac{P l^{2}}{8 D}
$$

where $\mathrm{D}$ is the flexural rigidity, calculated as

$$
D=\frac{E_{c m} \delta^{3}}{12(1-v)}
$$

$l$ - characteristic length,

$$
l=\sqrt[4]{\frac{D}{k}}
$$

$E_{c m}$ - slab concrete stress-strain modulus; $k$ - coefficient of the soil reaction, depends upon the type of the subsoil, according to [1] $k=2760 \mathrm{t} / \mathrm{m}^{3} ; \delta$-slab thickness.

Subsoil reaction in the place of the greatest slab deflection

$$
\rho_{\max }=\frac{P}{8 l^{2}}
$$

Bending moment values may be easily calculated using the formulas [1]:

$$
\begin{aligned}
& M_{r}=D\left(\frac{d \varphi}{d r}+\frac{v}{r} \varphi\right) \\
& M_{t}=D\left(\frac{\varphi}{r}+v \frac{d \varphi}{d r}\right)
\end{aligned}
$$

Pavement slab reinforcement scheme (including the working draft) was elaborated by the specialists of the Building Constructions Department of O.M. Beketov National University of Urban Economy under the supervision of prof. V.S. Shmukler and is shown in Fig. 2. The reinforcement cage has two layers, is made of glass composite reinforcement $\varnothing 10 \mathrm{~mm}$ (Ekibar 10 AKSP TU U B.2.7-25.2-21191464-024:2011) housing parameters $150 \times 150 \mathrm{~mm}$, elastic hydraulic seal. The area of longitudinal extended non-metallic composite 


\section{Transbud-2018}

reinforcement for the slab was taken on the basis of provisions of section 9 DBN B.2.6-98, section 8 DSTU B B.2.6-156, and corresponding provisions of section 3 DBN B.1.1-12:

$$
A_{f, \min }=0.26 \frac{f_{c t m}}{f_{f k}} b_{t} d
$$

where $b_{t}$ is a medium width of the extended area; $f_{c t m}-$ medium concrete tension capacity determined for the corresonding strength category, according to DBN B.2.6-98, but not less than $0.0013 b_{t} d$.

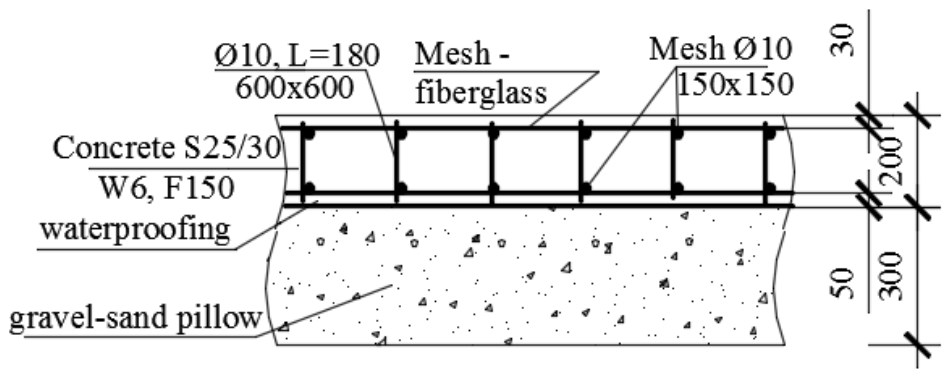

Fig. 2. General pavement slab reinforcement scheme.

Physical and mechanical characteristics of the glass composite reinforcement $\varnothing 10 \mathrm{~mm}$ (Ekibar 10 AKSP TU U B.2.7-25.2-21191464-024:2011) are shown in Table 2 [2].

Table 2. Physical and mechanical characteristics of the glass composite reinforcement.

\begin{tabular}{|c|c|c|c|c|c|c|}
\hline \multirow{2}{*}{$\begin{array}{c}\text { Reinforcement } \\
\text { class }\end{array}$} & \multicolumn{6}{|c|}{ Mechanical characteristics } \\
\cline { 2 - 7 } & $f_{f k}, \mathrm{H} / \mathrm{mm}^{2}$ & $\begin{array}{c}f_{f d}, \\
\mathrm{H} / \mathrm{mm}^{2}\end{array}$ & $f_{f c d}, \mathrm{H} / \mathrm{mm}^{2}$ & $E_{f^{\prime}} 10^{-3}, \mathrm{H} / \mathrm{mm}^{2}$ & $\varepsilon_{f u}, \%$ & $\varepsilon_{f_{0}}, \%$ \\
\hline AKS 600 & 600 & 400 & 100 & 50 & 1.2 & 0.80 \\
\hline
\end{tabular}

The shank spacing of the main longitudinal non-metallic composite reinforcement does not exceed $3 h$ and is smaller than $400 \mathrm{~mm}$ ( $h$-slab length). In the localized load or maximum torque areas, the shank spacing of the main reinforcement does not exceed $2 \mathrm{~h}$ and is less than $250 \mathrm{~mm}$.

The determination of slab bearing capacity at the suggested variant of reinforcement is conducted with the help of calculation software elaborated (based on the library DSTU_156.dll) by the specialists of the Building Constructions Department of O.M. Beketov National University of Urban Economy [4]. The calculation results are shown in graphic form (fig. 3-5).

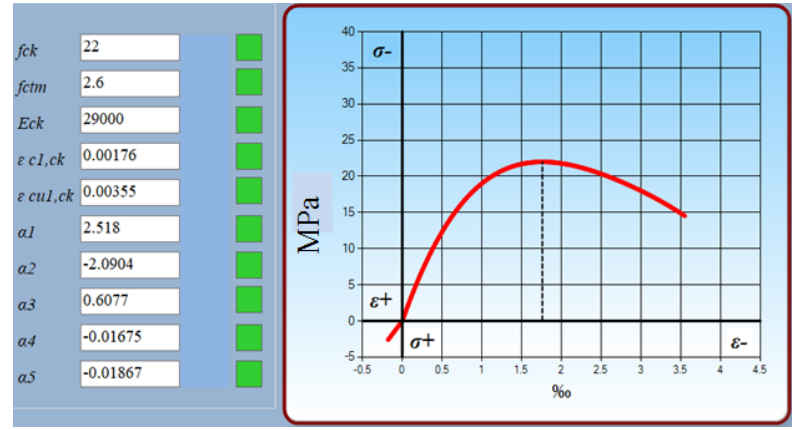

Fig. 3. The objective of physical and mechanical characteristics of concrete. Screenshot of the application window. 


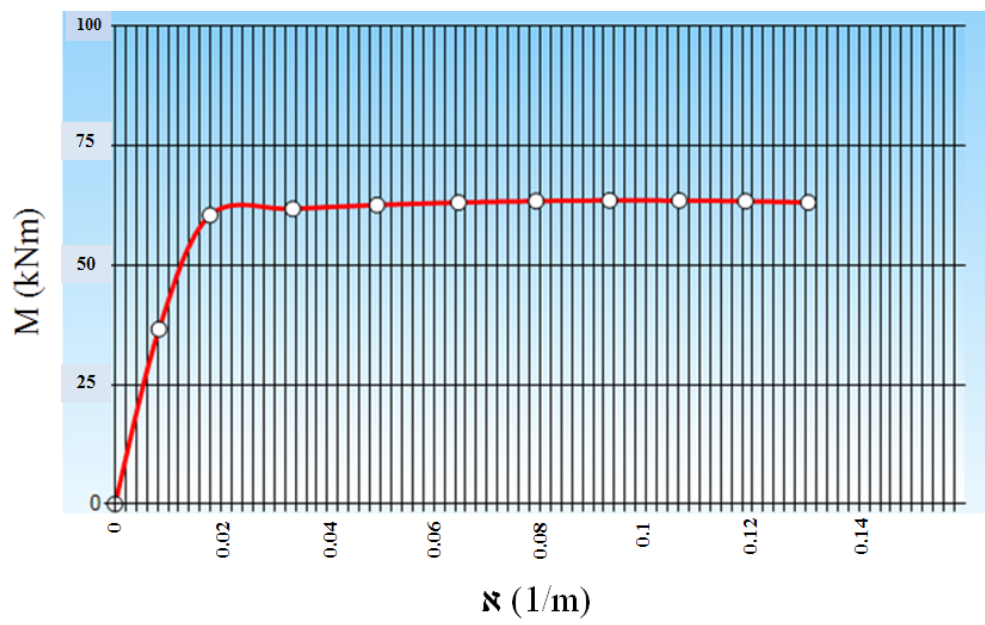

Fig. 4. The sectional diagram «torque-curve». Screenshot of the application window.
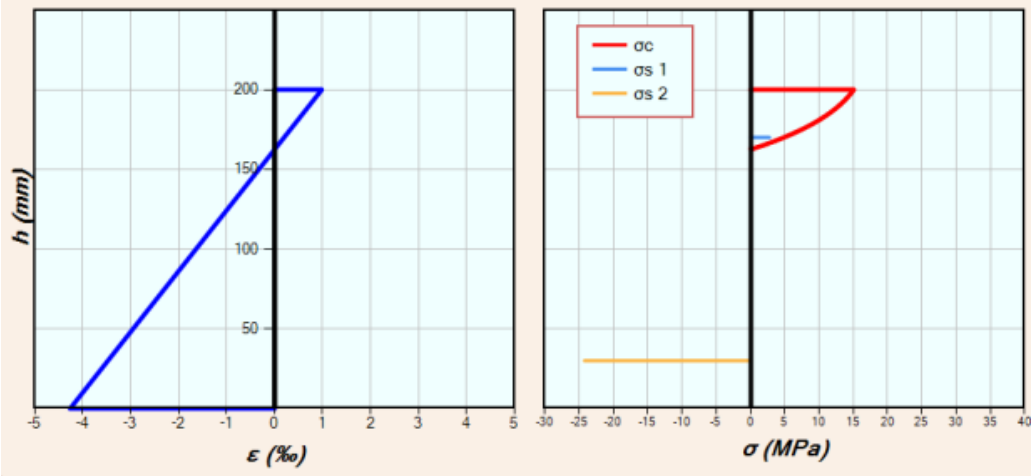

Fig. 5. The strain $\varepsilon$ and stress $\sigma$ diagram. Screenshot of the application window.

The table of results contains the strain $E_{p s}(\%)$ on both section planes, torque $M(\mathrm{kNm})$, height of the compressive zone of the concrete $x_{1}(\mathrm{~mm})$, section curve $\boldsymbol{\aleph}(1 / \mathrm{m})$.

Table 3. The table of results.

\begin{tabular}{|c|c|c|c|c|c|}
\hline № & $\begin{array}{c}E_{p s} c(1) \\
(\% \mathbf{0})\end{array}$ & $\begin{array}{c}E_{p s} c(2) \\
(\% \mathbf{0})\end{array}$ & $M(\mathrm{kNm})$ & $x_{I}(\mathrm{~mm})$ & $\boldsymbol{\aleph}(1 / \mathrm{m})$ \\
\hline 1 & 2 & 3 & 4 & 5 & 6 \\
\hline 1 & 0.0656 & -1.0222 & 7.1444 & 24.1211 & 0.00272 \\
\hline 2 & 0.1312 & -2.0183 & 14.0967 & 24.4152 & 0.00537 \\
\hline 3 & 0.1968 & -2.9887 & 20.8612 & 24.712 & 0.00796 \\
\hline 4 & 0.2624 & -3.9341 & 27.4425 & 25.0113 & 0.01049 \\
\hline 5 & 0.328 & -4.8551 & 33.8447 & 25.313 & 0.01296 \\
\hline 6 & 0.3936 & -5.7523 & 40.0722 & 25.6172 & 0.01536 \\
\hline 7 & 0.4592 & -6.6262 & 46.1291 & 25.9337 & 0.01771 \\
\hline 8 & 0.5248 & -7.4774 & 52.0197 & 26.2326 & 0.02001 \\
\hline 9 & 0.5904 & -8.3066 & 57.7481 & 26.5438 & 0.02224 \\
\hline 10 & 0.656 & -9.1142 & 63.3183 & 26.8572 & 0.02443 \\
\hline
\end{tabular}

Bearing capacity of the slab section turned out to be enough to bear the operational load. 


\section{Technology of slab reinforcement}

The arrangement of the pavement slab of Pavlivska Square was conducted within the short period of time. Due to this, for the purpose of mounting the two-layer reinforcing cage of the slab, the workers of Ekipage Technological Group elaborated a new mounting method which allows the essential reduction of the performance time. According to the reinforcement scheme - the sickness of the concrete slab is $200 \mathrm{~mm}$; the distance from the lower grid of the reinforcing cage to the hydraulic seal layer is $50 \mathrm{~mm}$; the thickness of the concrete wall protection layer is $30 \mathrm{~mm}$. The distance of the lower grid of the reinforcing cage from the hydraulic seal layer is provided for by the supporting elements, distributed around the lower grid (fig.6).

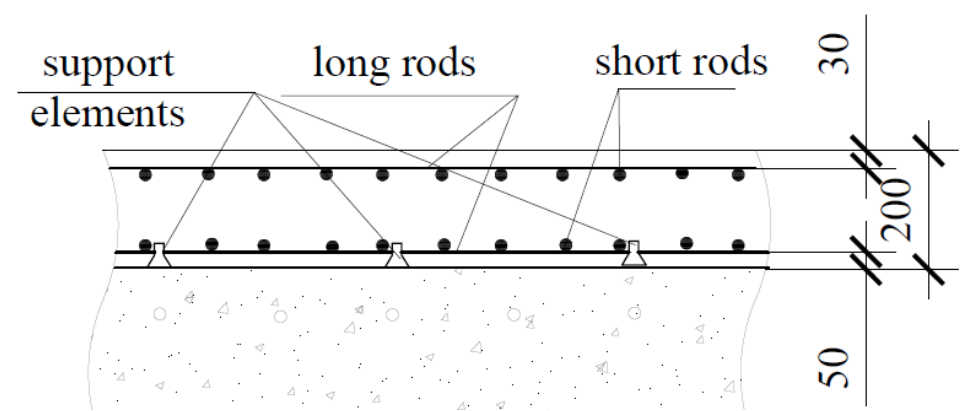

Fig. 6. General reinforcement scheme through the thickness of the concrete slab.

The sequence of mounting the supporting elements (SE), $h=50 \mathrm{~mm}$, is performed according to 5-point envelope scheme, with their installation with the spacing of $1 \mathrm{~m}$. The scheme of the SE location is shown in fig.7. SE are installed directly on the fitting shanks of the lower grid chart, which, in their turn, are located in the future lower slab area, which rests on the soil (elastic cushion). In this case, necessary thickness of the protective layer of concrete is ensured due to the SE installation.
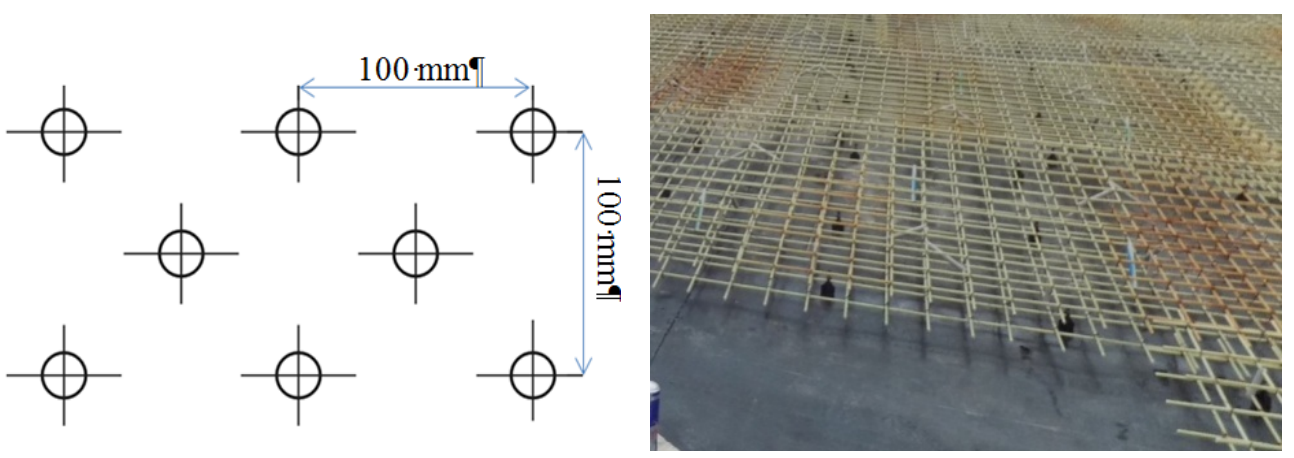

(a)

(b)

Fig. 7. The scheme of the SE location (a) and standard form of SE at the building site (b).

The peculiarity of formation of the spatial reinforcing cage is the installation of mounting elements inside it. And, in particular, the vertical pillar (VP), $L=96 \mathrm{~mm}$, designed for the installation as a bridging, perpendicular grid plane, to ensure the design spacing between the lower and upper grids of the reinforcing cage. Short Rod (ShR), $L=191 \mathrm{~mm}$, is used for the installation as diagonal bridging between the internal parallel reinforcing shanks of upper and lower grids of the reinforcing cage. Long Rod (LR), $L=196 \mathrm{~mm}$, (marked with the paint) necessary for the installation as diagonal bridging 
between the external parallel reinforcing shanks. General pattern of the installation of VP, ShR and LR is shown in fig. 8-9. VP are installed on the internal reinforcement shanks of the reinforcing cage, right against the grid nodes, near the SE fixing (fig.8). ShR are installed on the internal parallel reinforcing shanks of the reinforcing cage grids, in the housing adjacent to the earlier installed SE. ShR are installed between the parallel internal reinforcing shanks (fig. 8) LR are installed on the external parallel reinforcing shanks of the reinforcing cage grids, in the housing adjacent to the earlier installed SE. ShR are installed between the parallel internal reinforcing shanks (fig. 8-9).

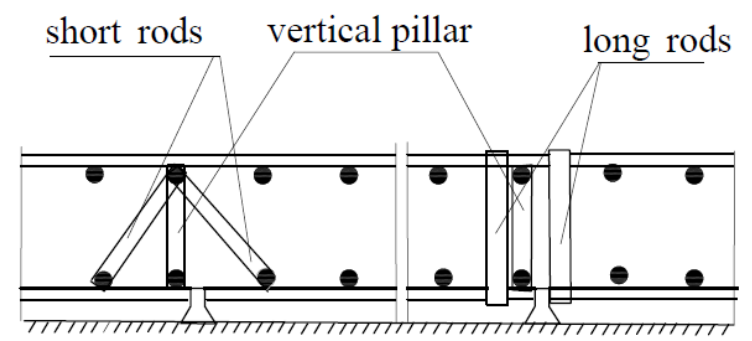

Fig. 8. General pattern of the installation of vertical pillar (VP), Short Rod (ShR) and Long Rod (LR).

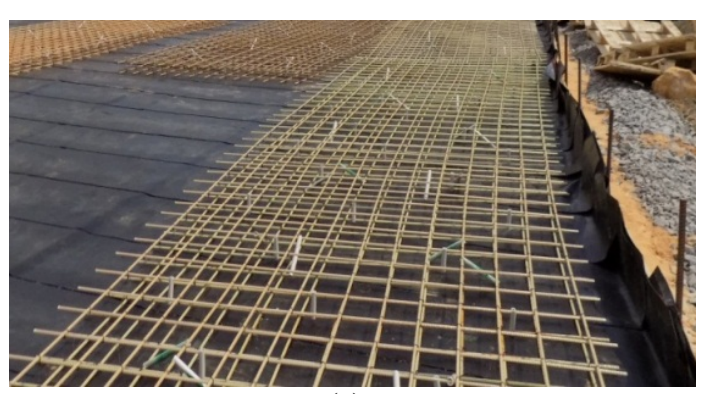

(a)

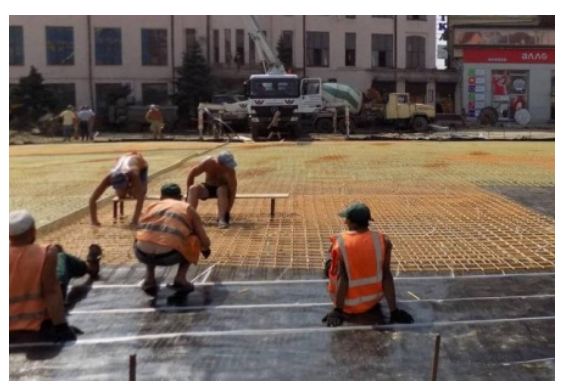

(b)

Fig. 9 a, b. Installation of vertical pillar (VP), Short Rod (ShR) and Long Rod (LR).

To prevent the shifting of upper grid against the lower, during the mounting operations of reinforcing cage and its filling with the concrete, the pairs of ShR and LR shall be mounted in chessboard order, according to fig. 10.

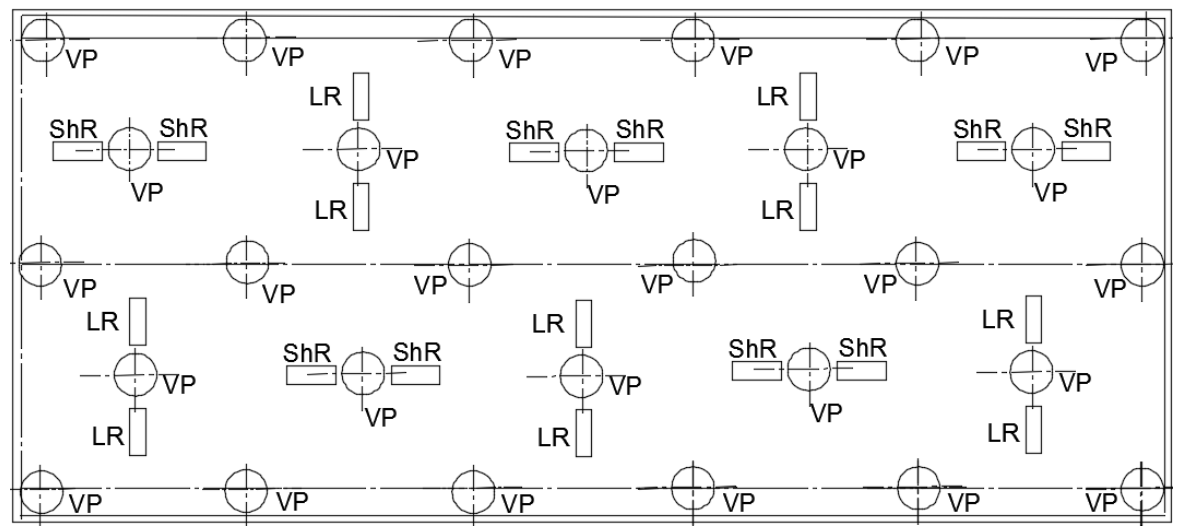

Fig. 10. General pattern of the bracing elements location (in the plan) around the reinforcing cage.

The general order of the reinforcing cage mounting is as follows: the composite grids of the lower reinforcement cage band are installed and interconnected (according to the design 
documentation); composite grids of the upper reinforcement cage band are installed and interconnected directly on the lower band (according to the design documentation), as a rule, with the half-section flooring; between the upper and lower bands reinforcing the pillars (VP) and brackets (ShR and LR) are installed, besides, in this case the mounting bunks with the supports are used, the construction of which does not damage the below hydraulic seal layer; final operation of mounting the two-layer reinforcing cage is the procedure of lifting the reinforcement cage on the supporting elements (SE) (fig. 11).

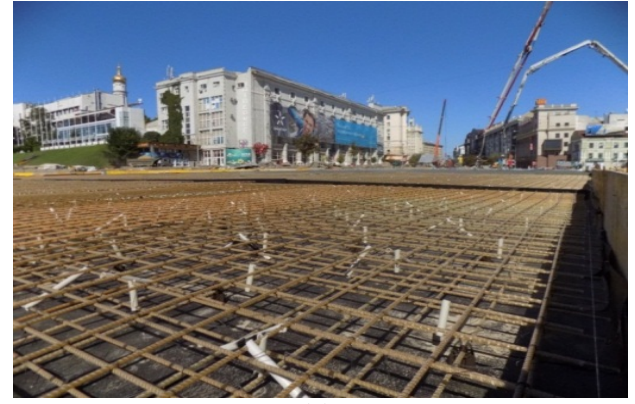

(a)

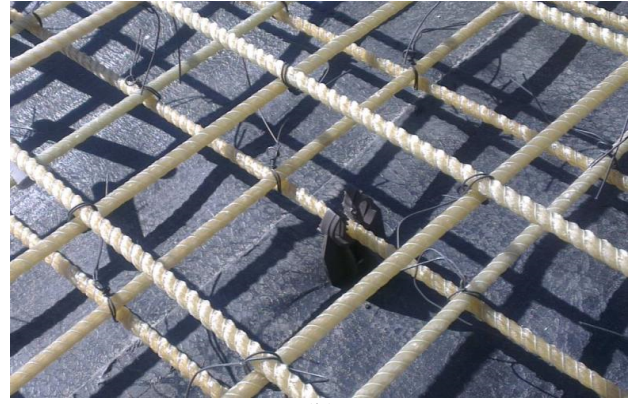

(b)

Fig. 11. The reinforcement cage lifted on the supporting elements (SE).

Final stage of the slab building is filling the reinforcing cage with the concrete according to the design documentation (fig.12).

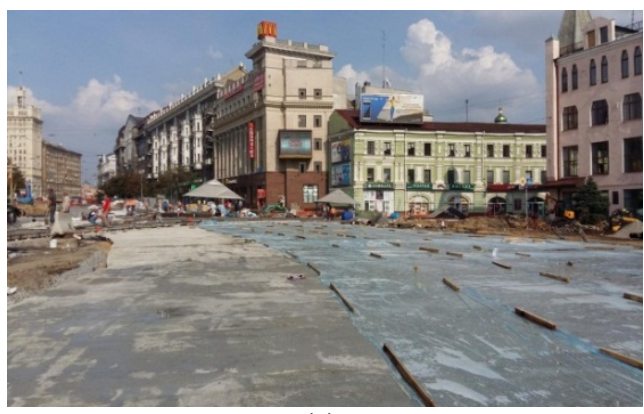

(a)

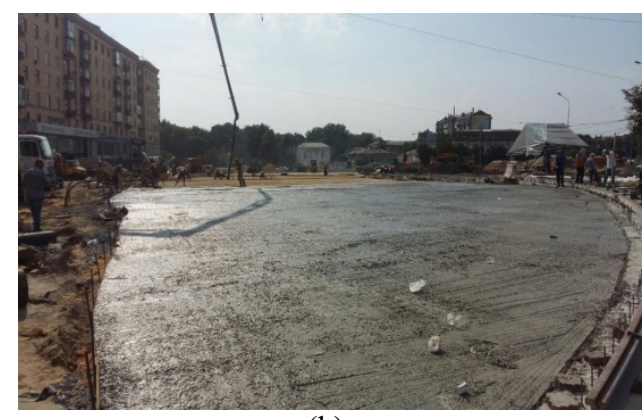

(b)

Fig. 12 a, b. Filling the reinforcing cage with the concrete.

\section{Conclusions}

General technical and statistical data on the realized project of reinforcing composite cage of the pavement slab in Pavlivska sq., Kharkiv, are as follows:

1. Total area of the concrete slab with the composite two-layer reinforcing cage is 8.7 ths. sq.m.

2. The tear resistance of the two-layer reinforcing cage of the composite reinforcement manufactured by Ekipage Technological Group is $420 \mathrm{kN} / \mathrm{m}$.

3. The amount of meters of the composite reinforcement manufactured by Ekipage Technological Group (“Ekibar” AKSP-10-800 TU U B.2.7-25.2-21191464-024:2011), used for the reinforcement cage arrangement is $260 \mathrm{~km}$.

4. Total weight of the composite reinforcement used for the reinforcement cage arrangement is 41 tons.

5. Total amount of the binding points for the reinforcing cage construction is 879040 pieces. 
6. Total amount of the binding points for the standard grids-charts $6 \times 2 \mathrm{~m}$ under the plant conditions -852800 pieces.

7. Total amount of the binding points for mounting the standard two-layer building blocks (sandwiches) to the mounted slab reinforcement cage at the building site is 26240 pieces.

8. The comparative amount of binding points in case of steel reinforcement, (mounting according to the traditional technology with the application of Z- or U-shaped inter-layer insertions-spacers) - 1036480 pieces.

As a result of applying the new quick mounting technology of the two-layer composite reinforcement cage the following was achieved:

1. Reduction of the total amount of binding points of the reinforcement cage by $15.2 \%$.

2. Reduction of the total labor intensity of the reinforcement cage mounting by $35 \%$.

3. Reduction of the labor intensity of the reinforcement cage mounting directly at the building site by more than 10 times.

\section{References}

1. S.P. Timoshenko, Plastinki i obolochki.469 (1948)

2. DSTU-N B V.2.6-185:2012: Nastanova z proektuvannia ta vyhotovlennia betonnykh konstruktsii z nemetalevoi kompozytnoi armatury na osnovi bazalto- $i$ sklorovinhu Kiev, Minrehion Ukrainy (2012)

3. DBN V.2.6-98:2009: Betonni ta zalizobetonni konstruktsii. Osnovni polozhennia Kiev, Minrehion Ukrainy (2011)

4. V.M. Babaiev, A.M. Bambura, O.M. Pustovoitova, V.S. Shmukler Praktychnyi rozrakhunok elementiv zalizobetonnykh konstruktsii za DBN V.2.6-98:2009 u porivnianni z rozrakhunkamy za SNiP 2.03.01-84* i EN 1992-1-1 (Eurocode 2). 208 (2015)

5. Yu.A. Klimov, D.O. Orieshkin, O.S Soldatchenko, Eksperymentalni doslidzhennia zcheplennia kompozytnoi nemetalevoi armatury $z$ betonom, Teoriia i praktyka budivnytstva. 71. 3, 237-241 (2010)

6. D.O. Orieshkin, Kompozitnye geosetki dlya armirovaniya nezhestkikh dorozhnyh odezhd. Proceedings of the Suchasni tekhnologhii budivnytstva j ekspluatasii avtomobiljnykh dorih. 220-225 (2013)

7. O.S. Chapiuk, A.V. Hryshkova Porivnialnyi analiz zcheplennia stalevoi armatury serpovydnoho profiliu z vazhkym betonom za pryzovym ta balkovym metodom vyprobuvan. Resursoekonomni materialy, konstruktsii, budivli ta sporudy, 29, 391-399 (2014)

8. J.J. Luchko, I.I. Ghlaghola, B.L. Nazarevych Metody pidvyshchennia koroziinoi stiikosti ta dovhovichnosti betonnykh ta zalizobetonnykh konstruktsii i sporud. 229 (1999)

9. L.C. Bank, M. Puterman Microscopic study of surface degradation of glass fiberreinforced polymer rods embedded in concrete castings subjected to environmental conditioning. ASTM International, 2, 191-205 (1997)

10. E. Cosenza, G. Manfredi, A. Nanni Composites in Construction: A Reality. Proceedings of the International Workshop. Capri. 277 (2001)

11. Dzh. Sendetski (ed.) Mekhanika kompozitsionnyh materialov. 2. 8, 564 (1978)

12. L.Yu. Ogrel Povyshenie effektivnosti stroitelnyh polimernyh kompozitov, ekspluatiruemyh v agressivnyh sredah. PhD Thesis. Belgorod. 40 (2006) 